\title{
Species Test of Morus alba and Morus cathayana in Indonesia
}

\author{
Nanang Sasmita ${ }^{*}, 1$ Liris Lis Komara ${ }^{1}$ \\ ${ }^{1}$ Forestry Department, East Kutai School of Agriculture. Jl. Soekarno-Hatta No. 01, Sangatta, East Kutai, East \\ Kalimantan, Indonesia \\ *Corresponding author. Email: sasmitana@yahoo.com
}

\begin{abstract}
Mulberry plants have been cultivated for a long time ago. It is being grown for the supply of silkworms. Mulberry cultivation as a silkworms feeds in Indonesia increases because mulberry plants have many benefits, including leaves and fruit as animal feed, tea production, and pharmaceuticals. This study aims to select the right Mulberry species for silkworms cultivation in Indonesia. The study was conducted at BPTH Bali, Cianjur Natural Silk Nursery (West Java), and East Kutai Agricultural Nursery (East Kalimantan). The method used with Randomized Block Design (RBD) consists of mulberry type treatments (Morus alba and Morus cathayana) with the provision of growth regulators (Rootone F). The research results from 3 mulberry species locations studied showed that $M$. alba showed an optimal growth in West Java, Bali, and East Kalimantan. The results showed that $M$. alba species had a growth percentage $(95 \%)$, shoots length (height) $(80 \mathrm{~cm})$, stem diameter $(0.82 \mathrm{~cm})$, number of shoots (4 branches), and number of leaves (20 strands). Where $M$. cathayana growth percentage (90\%), shoots length (height $(76 \mathrm{~cm})$, stem diameter $(0.75 \mathrm{~cm})$, number of shoots ( 3 branches), and number of leaves (18 strands). Overall, M. alba and M. cathayana are the types used to manage silkworms in Indonesia. The best mulberries type of the whole parameter is M. albafrom West Java region.
\end{abstract}

Keywords: Morus alba, Morus cathayana, Percentage of Growth, Cutting High, Number of Leaf

\section{INTRODUCTION}

Mulberry is a fast-growing shrub or a medium-sized tree species. Mulberry is also woody and broad-leaved plant. Mulberry plants have been cultivated for silkworm maintenance for a long time. Morus alba grows in an area with a tropical and subtropical climate. These plants are shade-resistant tree species. It usually grows in the dwindling regions, valley areas, and coastal areas. It can adapt and grow at an altitude of 0-3300 masl. The average annual temperature ranges from 0 $40^{\circ} \mathrm{C}$ with an annual rainfall average $1500-2500 \mathrm{~mm}$. This plant grows in various soils ranging from sandy clay to clay, but it prefers alluvial soil clay with adequate moisture and $\mathrm{pH}$ 6.0-7.5. The crop should be trimmed to regulate its shape and allow new shoots to minimize the mulberry competition. The shape depends on the height of the plant and the height of the cut branch. In India, the mulberry is up to 20 years old. $M$. alba growth shows an average diameter increase of 1.5 $\mathrm{cm}$ each year and an average height increase of $1 \mathrm{~m}$ per year. Mulberry experienced very rapid initial growth. It is about $4.5 \mathrm{~m}$ in the first two years. The Mulberry plant is native in Cambodia, China, India, Indonesia, Japan, Laos, Myanmar, Pakistan, Thailand, Vietnam, and Zanzibar. While in Ethiopia, France, Italy, Kenya, Korea Republic, Malaysia, Mozambique, Namibia, Nepal, South Africa, Tanzania, Uganda, and England are exotic species [1].

The main obstacle of natural silk in Indonesia is mulberry productivity, which is still relatively low, about 8 ton/ha/year, compared to mulberry productivity in China which could reach 22 ton/ha/year [2]. Increased production of mulberry leaves was done in various ways, including breeding, cultivation such as seed propagation (cuttings), and biotechnology. This problem can be solved by introducing a superior mulberry species to the sub-tropical states with excellent natural silk production. To improve mulberry productivity, it also needs a proper cultivation technique, a fast and economical mulberry breeding technique that fits Indonesia's climatic conditions. Another problem is the cuttings use efficient short-size 

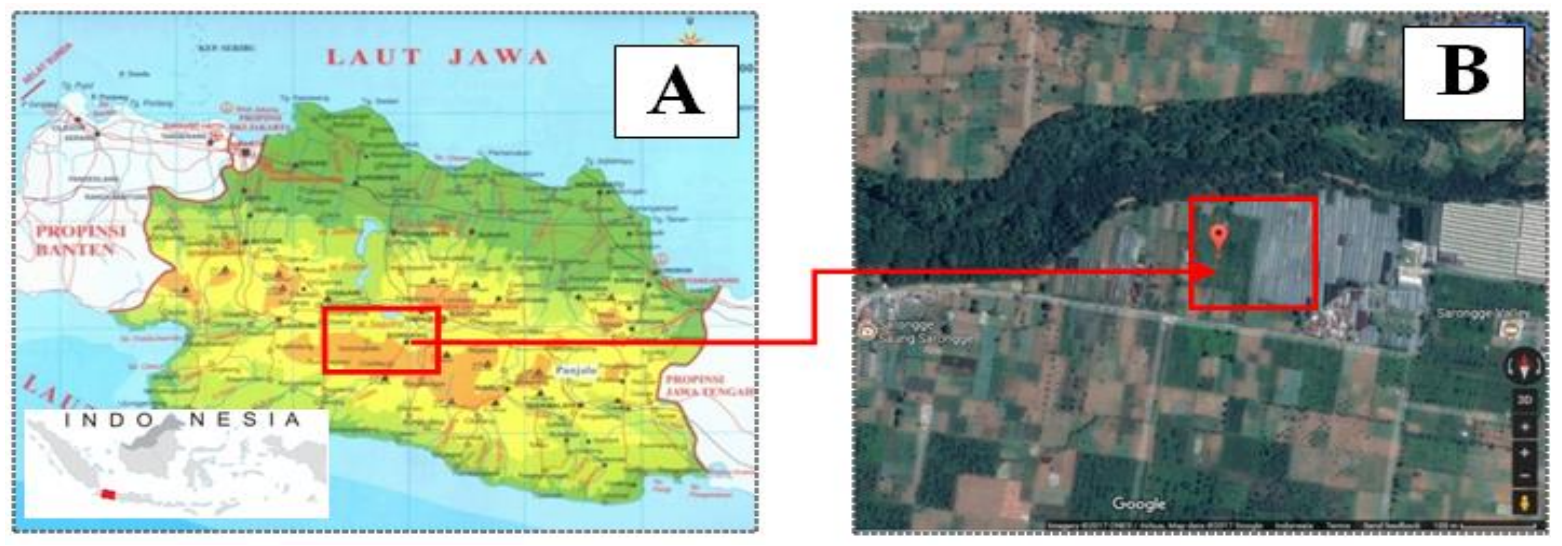

Figure 1 Research Sites in West Java Province (A) Indonesian Jalasutra Nature Production Center, Pasir Sarongge Village, Pacet Peak, Cianjur Regency at position 6²5'57.3"S and 10702'33.6"E (B)

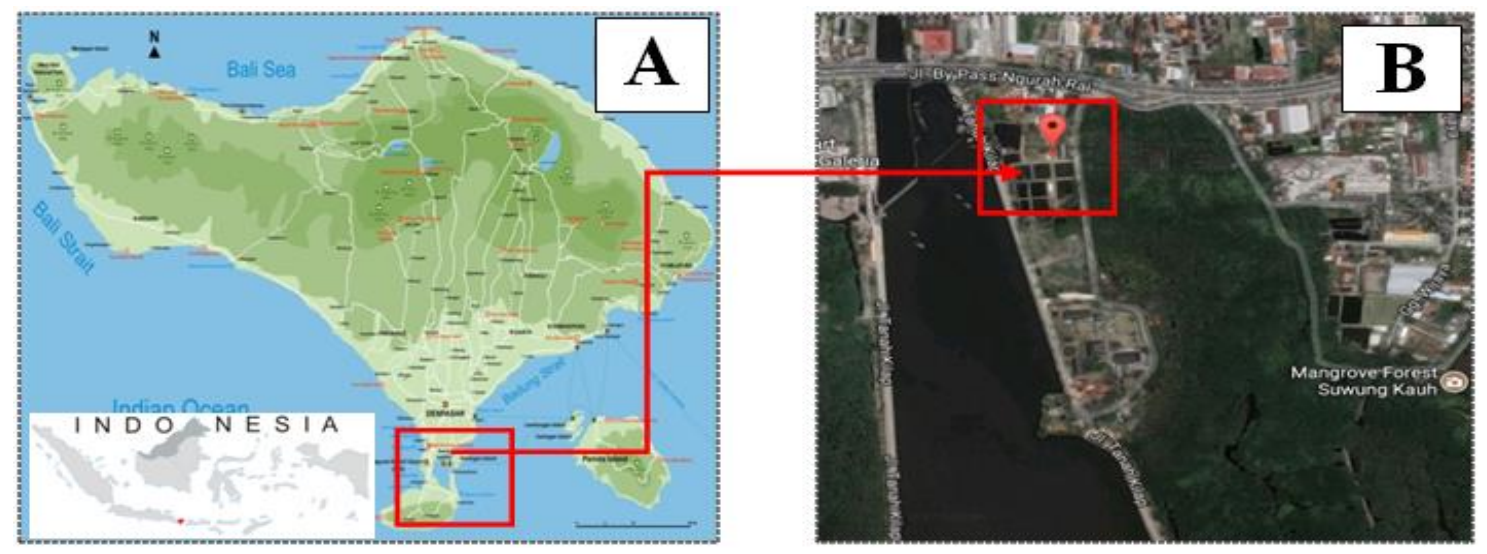

Figure 2 Research Sites in Bali Province (A) Forest Plant Breeding Center (BPTH) in Ngurah Rai streets Denpasar at $8^{\circ} 43^{\prime} 22.4^{\prime \prime S}$ and $115^{\circ} 11^{\prime} 20.0^{\prime \prime} \mathrm{E}(\mathrm{B})$
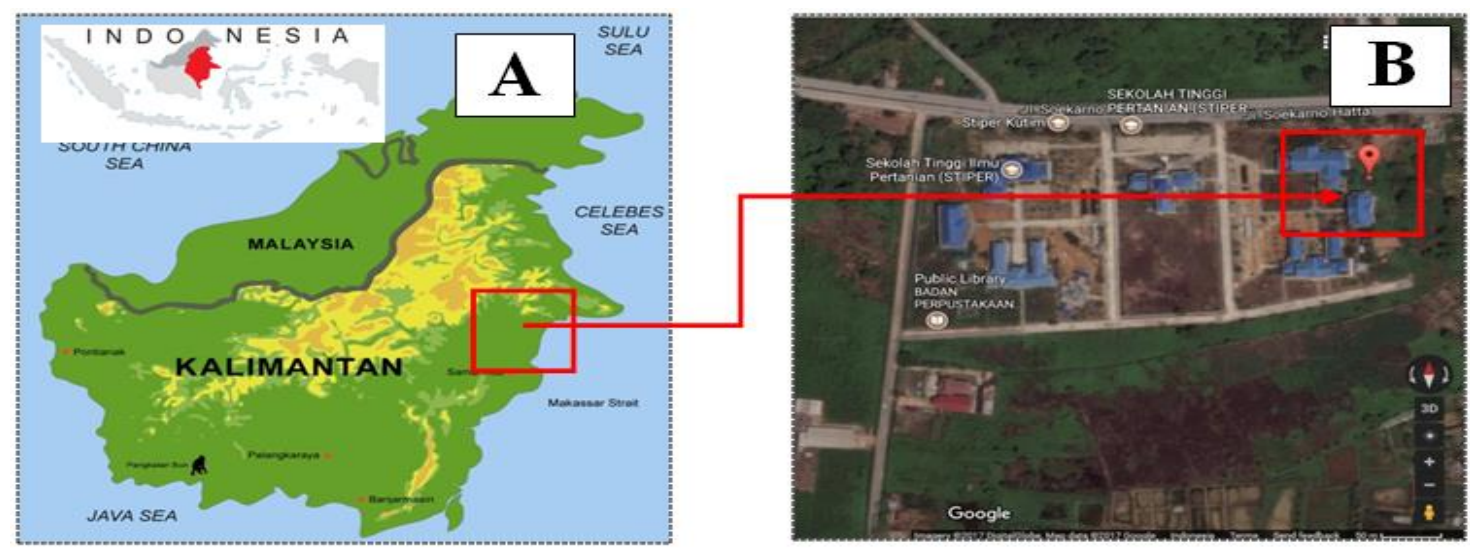

Figure 3 Research Sites in East Kalimantan Province (A) East Kutai Regency Agriculture Nursery at $0^{\circ} 31^{\prime} 60.0 " \mathrm{~N}$ and $117^{\circ} 33^{\prime} 47.0^{\prime \prime} \mathrm{E}(\mathrm{B})$

cuttings without reducing the ability to live and growth which means saving the use of the cuttings. For difficult areas to obtain cuttings, especially the superior type and very limited seed stock, it is needed to use cuttings efficiently. It is needed to study the most optimal mulberry adaptation to increase the growth of various mulberry types to achieve efficient use of cutting material. This study aims to determine the rate of adaptation and growth of mulberry in three different regions and Indonesia's environmental conditions. 


\section{MATERIALS AND METHODS}

\subsection{Study Area}

The research was conducted in three different areas: West Java, Bali, and East Kalimantan center of natural silk development in Indonesia. The first location is in Indonesia Nature Silk Centre, at Pasir Sarongge Village, Cianjur Regency (Figure 1). The second location is in the Forestry Plant Breeding Center (BPTH) Bali Nusa Tenggara in Ngurah Rai Street Denpasar Bali (Figure 2 ). The third location is in the Agricultural nursery of East Kutai Regency. The study was undertaken to test mulberry plant species in post-mining areas (Figure 3).

\subsubsection{Cuttings planting}

After cuttings are treated with the hormone Rootone $\mathrm{F}$ and organic growth regulator, subsequent cuttings are planted in polybags. The polybag size is $15 \mathrm{~cm} \times 25 \mathrm{~cm}$. The soil media for polybag content is topsoil (fertile soil). The weight of the soil media content and the mixture of manure is $3 \mathrm{~kg}$ per polybag. Comparison of soil and manure media is $2 \mathrm{~kg}$ of soil and $1 \mathrm{~kg}$ of manure. Manure used is from manure cow dung.

\subsubsection{Seeds maintenance}

Mulberry seedlings are maintained regularly for three months. Plant maintenance is done by cleaning the grass or dirt in polybag media. Watering seeds is done every day in the morning and evening.

\subsubsection{Measured Parameter}

The growth of mulberry seeds was measured to determine the treatment's effect on various kinds of mulberry. The mulberry seeds measurement was done every week for three months. These measurements include the length (height) of the seed, the seedlings' diameter, the number of branches, the number of leaves, and the percent of growth. Here are the technical guidelines for measuring mulberry seeds. Growth percentage (\%) was calculated based on live plant seedlings. The length (height) of the shoot (in $\mathrm{cm}$ ) was measured from the buds' base to shoots. Stem diameter (in $\mathrm{cm}$ ) was measured two $\mathrm{cm}$ from the bottom of the stem. The number of shoots was calculated based on the number of shoots that grow each cutting. The number of leaves was calculated on the leaves that have grown.

\subsection{Procedures}

The research procedures were: taking cuttings, planting cuttings, planting cuttings maintenance (seed), and parameter measurement.

\subsubsection{Cuttings}

Mulberry cuttings were taken from two-year-old plants, Sarongge Village, Cianjur Regency, in good condition, free from pests and diseases. The cuttings are cut into $30 \mathrm{~cm}$ length using a sharp knife to produce smooth cuts, so the reductions form callus quickly. The callus formed on mulberry cuttings is useful to cover the wound [3]. Taking cuttings was done in the afternoon to multiply the roots' exit and inhibit evaporation by cutting the plant's stem part. The cuttings' bottoms were cut oblique $45^{\circ}$ while the top is trimmed flat with a 0.5 $2.0 \mathrm{~cm}$ diameter. Some mulberry cuttings which been taken are 180 cuttings of $M$. alba and 180 cuttings of $M$. cathayana. Total mulberry cuttings are 360 cuttings for each research location.

\subsubsection{Provision of Treatment}

After the cuttings of two types of mulberry plants are taken, then given treatment, the cuttings are soaked at the base into the Rootone $\mathrm{f}$ hormone, Organic growth regulator, and no treatment as a control.

\subsection{Data Analysis}

In the research, the measurement data were analyzed on plant species' effect on the growth and mulberry adaptation at three different locations. Data were analyzed by analyzing variance (ANOVA), followed by Duncan Multiple Range Test (DMRT) at a 5\% level. Determination of the best treatment of all experimental parameters. The ranking is made from the highest to the lowest number. The liveability percentage parameter is an indicator to determine the success of mulberry seedlings so that the value weight of the life ability percentage is higher.

\section{RESULTS}

\subsection{Percentage Growth (\%)}

The growth percentage in Kalimantan is lower than in West Java. Compared to East Kalimantan, the growth percentage in Bali is higher. The growing rate of root one $\mathrm{f}$ treatment could increase mulberry plants in West Java for $M$. alba (95\%) and M. cathayana (90\%) compared with the organic matter treatment for $M$. alba (75\%) and $M$. cathayana (75\%) as well as control for $M$. alba $(70 \%)$ and $M$. cathayana $(65 \%)$.

\subsection{Cutting High (cm)}

High growth (Table 1) shows that, in general, the cuttings continue to increase. The high of $M$. alba and $M$. cathayana in West Java and Bali is higher than in East Kalimantan. The highest average cuttings rate at 90 days after planting is rootone $\mathrm{F}$ treatment followed by 
Table 1. The average of three month old percentage of growth, high, number of leaf, diameter and branch of Morus alba (MA) and Morus cathayana (MC)

\begin{tabular}{lcccccccccccc}
\hline \multirow{2}{*}{ Parameter } & Species & \multicolumn{3}{c}{ West Java } & \multicolumn{3}{c}{ East Kalimantan } & \multicolumn{3}{c}{ Bali } \\
& & $\mathrm{R}$ & $\mathrm{O}$ & $\mathrm{C}$ & $\mathrm{R}$ & $\mathrm{O}$ & $\mathrm{C}$ & $\mathrm{R}$ & $\mathrm{O}$ & $\mathrm{C}$ \\
\hline \multirow{2}{*}{ Percentage of Growth (\%) } & MA & 95 & 75 & 70 & 80 & 75 & 60 & 85 & 75 & 65 \\
& $\mathrm{MC}$ & 90 & 75 & 65 & 75 & 75 & 50 & 80 & 75 & 65 \\
\hline \multirow{2}{*}{ High (cm) } & MA & 80 & 65 & 36 & 58 & 38 & 32 & 67 & 40 & 32 \\
& MC & 76 & 62 & 34 & 50 & 41 & 33 & 56 & 38 & 35 \\
\hline \multirow{2}{*}{ Number of Leaf (Strands) } & MA & 20 & 17 & 12 & 15 & 10 & 9 & 16 & 11 & 11 \\
& MC & 18 & 16 & 11 & 13 & 9 & 8 & 13 & 11 & 10 \\
\hline \multirow{2}{*}{ Diameter (cm) } & MA & 0.82 & 0.42 & 0.30 & 0.49 & 0.41 & 0.28 & 0.55 & 0.41 & 0.29 \\
& MC & 0.75 & 0.43 & 0.30 & 0.45 & 0.39 & 0.25 & 0.48 & 0.40 & 0.31 \\
\hline \multirow{2}{*}{ Number of branches } & MA & 4.00 & 3.00 & 2.00 & 2.00 & 2.00 & 2.00 & 3.00 & 2.00 & 2.00 \\
& $M C$ & 3.00 & 3.00 & 2.00 & 2.00 & 2.00 & 2.00 & 2.00 & 2.00 & 2.00 \\
\hline
\end{tabular}

organic matter and control. From the picture, it is seen that rootone $\mathrm{F}$ influences the growth of cuttings of $M$. alba and M. cathayana. It is along with another research that reported that treatment of growth regulators affected plant seedlings [4].

\subsection{Mulberry Plants Number of Leaves (Strands)}

The mulberry plant (Table 1) produces a favorable response to the number of leaves due to a place condition M. alba and M. cathayana, in West Java and Bali, which make leave more than in East Kalimantan. The mulberry plant also has more leaves due to rootone $\mathrm{F}$ treatment. The rootone treatment has the best response on $M$. alba and $M$. cathayana compared with the organic growth regulators treatment. In contrast, the mulberry without rootone $\mathrm{F}$ treatment and organic growth regulators (control) have the lowest value.

\subsection{Growth Diameter of Mulberry Cuttings}

Growth of diameter (Table 1) shows that, in general, the diameter of cuttings continues to increase. Diameter growth in West Java and Bali is more than in East Kalimantan. The highest average diameter of cuttings after 90 days of mulberry planted was on rootone $\mathrm{F}$ treatment followed by organic matter and control. From the table, giving rootone $\mathrm{F}$ influences the growth $M$. alba and $M$. cathayana cuttings. Hormone treatment affects plant growth [5].

\subsection{Number of Mulberry Cuttings Branches (Buds)}

The number of mulberry cuttings branches in West Java and Bali is more than in East Kalimantan. The rootone treatment of $15 \mathrm{ppm}$ is the appropriate treatment for the growth of the number of mulberry plant shoots
(Table 1). Rootone can help increase the performance of auxins present in the plant, thus increasing shoot growth. The performance of exogenous and endogenous hormones produced by roots can support plant buds' growth [5]. It is suggested that exogenous and endogenous hormones can trigger buds' growth; otherwise, it will prevent apical dominance so that bud growth is not inhibited [5].

\section{DISCUSSION}

\subsection{Biophysical Condition}

The biophysical condition location affects the mulberry plant's cultivation, namely temperature, humidity, air quality, airflow, and light. It is crucial to adjust the microclimate for the mulberry plant adaptation and can produce many mulberry leaves. The ideal conditions for mulberry cultivation range from 15$30^{\circ} \mathrm{C}$, and humidity ranges between 65 and 90\% [7]. The Cianjur area of West Java is the near-optimal condition for mulberry cultivation. Mulberry cultivation is suitable to be done at an altitude of 700-3000 m asl. There is enough sunlight. Rainfall between 2500-3000 $\mathrm{mm}$ per year in an equally divided condition is eight months wet and four months dry. Thus, the peak area of Cianjur, West Java, with 900-2000 m above sea level altitude, including the ideal place for mulberry cultivation, maintenance of silkworms, and good effect on the quality and quantity of cocoon produced.

Rainfall in Bali Island is generally included in the monsoonal rainfall pattern. Concerning the mulberry plant adaptation test, the Bali area has a good adaptation. However, compared with the West Java region is still less optimal because of the relatively high temperature. Temperatures in East Kalimantan between $27-35^{\circ} \mathrm{C}$ with an annual rainfall average of 1700-2000 $\mathrm{mm}$. The rootone $\mathrm{F}$ use in mulberry plants in Bali and 
East Kalimantan initially gave a good effect, but high temperatures with high sunlight caused auxin not to work optimally. Lifting auxin will be degraded if exposed to high sunlight [5].

\subsection{Adaptation of Mulberry Plants}

Both mulberry plant types tried, it turns out $M$. alba has the highest adaptation in the Cianjur regency of West Java. It is proven by the result of live percentage, plant height, number of leaves, cuttings diameter, and the highest number of shoots. The $M$. alba at 90 DAP has a $95 \%$ live percentage (Table 2), $80 \mathrm{~cm}$ plant height (Table 3), 20 leaves (Table 4), diameter $0.82 \mathrm{~cm}$ (Table 5 ) and 4 cutting the highest(Table 6). The results are high in Indonesia's wet climates, as the percentage of live produced M. alba in Sulawesi is about $85 \%$ [8]. The highest percentage of life in $M$. alba is due to better adaptability to temperature and humidity than different species. This is indicated by the value of research results (about 90-95\%) which is not different between mulberry (Table 2). At the time of the cuttings' growth, there is no great competition for growth factors resulting in plant height, size of diameter, and the number of buds becomes relatively small for $M$. cathayana.

\subsection{Number of Leaves}

The highest number of leaves on $M$. alba and $M$. cathayana in West Java caused the mulberry growth index to be higher than in Bali and Kalimantan (Table 4 ). The high number of leaves causes the broader leaves surface to absorb solar radiation and increase photosynthesis and plant growth rate. The plants absorb more nutrients from the soil, especially nitrogen. In the end, the production of more assimilates to be translocated to the stems to produce more leaf [9]. However, in Bali and Kalimantan, although the number of leaves is lower (Table 4), mulberry plants still can grow well. High temperatures do not cause the leaves to wither or dry but remain fresh and green. The leaves that grow do not die but tend to be newer, greener, and usually grow. This suggests that the media's nutrients are simple elements easily absorbed by plant cuttings [10]. Nutrient absorption, especially nitrogen, causes the more high protein in plants' bodies, especially in the stems and leaves. The protein content in forage higher; otherwise, the fiber content is lower. High levels of crude protein cause low levels of green fiber [30]. The forage protein content of more than $7 \%$ is feasible as animal feed [11].

\subsection{The mulberry highest cutting diameter}

The highest cutting diameter average at 60 DAP is rootone treatment in West Java. Rootone $\mathrm{F}$ affects the cuttings diameter growth of M. alba and M. cathayana. Hormone treatment involves plant growth [12].
Compared to Bali and Kalimantan, although the number of leaves is lower, mulberry plants can still grow well. The low growth of diameter is more due to the less optimal factor of auxin hormone work. Auxin hormones are more easily exposed to sunlight. Other factors that affect the physiological conditions of the plant. A good cutting will produce the kind of mulberry plant which grows well. The physiological states of plants affecting the quality of cuttings are the age of the cuttings, the type of plants, young shoots and leaves, the supply of foodstuffs, and growth regulators [13]. The growth regulator substances used should be precise if excessive concentration will cause poisoning in the plant.

\subsection{Number of Mulberry Cutting}

Rootone treatment increased shoots growth in mulberry species $M$. alba and $M$. cathayana in West Java. Rootone $\mathrm{F}$ helps increase the amount of auxin work in the plant, growing shoots' growth. The performance of exogenous and endogenous hormones produced by roots can support plant buds' growth [6]. It is suggested that exogenous and endogenous hormones can trigger rupture of shoots and the growth of buds; otherwise, it will prevent apical dominance so that bud growth is not inhibited [5]. Compared to Bali and Kalimantan, shoots' appearance is slower (Table 6). However, the mulberry plant can still grow well. Slow shoot growth is more due to the less optimal factor of hormone auxin work. Auxin hormones are more easily exposed to sunlight [20]. The un-optimal of organic substances, in general, cannot be determined precisely. The effect of an organic substance on mulberry buds' growth is not significantly different between growth with organic addition and control because buds can still grow on the media without treatment. This is following the opinion of $[10,14]$. Auxin work to regulates the growth and development of plants through cell division, elongation, and differentiation [15]. IBA, auxin precursors which found as synthesis materials that induce root initiation in plants. IBA is used to help plant roots [16]. IBA compounds are considered highly synthetic. In some plants, IBA is synthesized in vivo using IAA and is an organosulfur compound of the formula (R2NCS2) other compounds as precursors. Another composition of rootone is Thiuramdisulfide [17]. Thiuram disulfide was obtained by oxidation of dithiocarbamates. This compound is used in the vulcanization of plants and pesticides.

\subsection{Adaptation of Mulberry in Indonesia}

Mulberry in various parts of Indonesia supports the silkworm business. In East Asian countries such as China, India, and Japan, mulberry is a conservation plant because it adapts to dry and barren land. This study examined mulberry adaptation of the dry land of Bali and Kalimantan. The results show that mulberry 
can grow and adapt in Bali and Kalimantan, although the growth rate is not optimal as in wet climate (West Java). In some countries, mulberry adapts to cold temperatures, hot temperatures, dry land, and floods. Mulberry plants can withstand drought, effectively withstand wind, stabilize sand and soil conditions. Currently, mulberry plants are used as an ecological plant species for soil and water conservation, especially for the conservation in upland areas [18]. Mulberry plants have high adaptability to the soil. The combination of mulberry plants with crops can increase the soil fertility value [19]. Soil with $\mathrm{pH}$ 5.3-8.4 is still growing naturally [20]. That is why the mulberry has a wide distribution and good growth. Mulberry plants have a strong survival. In arid or semiarid conditions, the desert region with rainfall of less than 300-600 mm, mulberry grows naturally. In the desert area of Xinjiang with $150 \mathrm{~mm}$ annual rainfall, it still grows well. Mulberry decreases leave by decreasing photosynthesis, transpiration rates, and water efficiency in droughtstress areas. The indication that the mulberry has a strong resistance to drought is that it grows chronically, and no one dies [21].

Mature mulberry plants adapt from water puddles during their growth period. It is sporadic among other xerophyte plants [18]. Mulberry plants that experience more than 1 meter deep still grow well. Mulberry plants resistant to cold [22]. The mulberry plant is resistant in cold conditions $\left(-30^{\circ} \mathrm{C}\right)$, and it also can survive in hot conditions $\left(40^{\circ} \mathrm{C}\right)$. For example, in America, with a wide geographical range, mulberry plants can grow in various climates. The mulberry grows in areas with humid subtropical climates, such as in Alabama $\left(27^{\circ} \mathrm{C}\right)$ with a summer. This occurs in Colorado's semiarid environments, with high temperatures and having a high potential of evapotranspiration rates. Based on Bali and Kalimantan's mulberry plants in Bali, which has a dry climate, the live plant percentage is still relatively good for $M$. alba and M. cathayana (75-80\%).

\section{CONCLUSIONS}

The best mulberry type of the whole parameter is $M$. alba from the West Java region. However, for other parameters of high cuttings, diameter, some leaves, and the number of shoots is relatively low for the Kalimantan region. The high-temperature factor strongly influences the low growth in Kalimantan because its position is right under the Equator line. Overall, the Morus alba species are more suitable with higher productivity than Morus cathayana. However, Morus cathayana can adapt to every location, even though its productivity is low.

\section{REFERENCES}

[1] C. Orwa, A. Mutua, R. Kindt, R. Jamnadass, A. Simons, Agroforestry database: a tree reference and selection guide version 4, 2009, Available at: www.worldagroforestry.org/af/treedb

[2] D. Mudiana, I.N. Lugrayasa, The effect of the cutting material origin with the growing regulators treatment on the growth of Hydrangea macrophylla Thunb, in: Proceedings of the one day seminar: Exploring the potential and improving the Prospect of Horticultural crops towards food security, Bogor Botanical Garden, LIPI.Bogor, $5^{\text {th }}$ Nopember 2000, 2001.

[3] B. Santoso, Comparison of plant growth and leaf production multiple varieties of crops mulberry results in rainy and dry season, Ujungpandang forestry research center, South Sulawesi, Forestry Research, 5, 1999, pp. 1-15.

[4] R. Wudianto, Instructions for using Pesticides, Penebar Swadaya, Jakarta, 1992.

[5] M.A.I. Pulok, M.M. Hossain, M.N. Haque, K.K. Poddar, S.G. Partho, M.S.H. Khan, Effect of organic and inorganic growth regulators on germination and vigour of chickpea seed, International Journal Business Socsci Res, 2(2), 2014, pp. 116-120.

[6] F.B. Salisbury, C.W. Ross, Plant Physiology vol. 3, D.R. Lukman, Sumaryono (Translator), ITB Publisher, Bandung, 1995.

[7] L.R.H. Panjaitan, J. Ginting, Haryati, Growth response of various sizes of bougenvil cut trunk stems (Bougainvillea spectabilis Willd) against growing regrowth substances, Journal of Agrotechnology, 2(4), 2014, pp. 1384-1390.

[8] I.W. Nursita, Productivity Comparison of two different places in the heat maintenance environment conditions, Journal of Animal Science, 21(3), 2011, pp. 10-17.

[9] F.P. Gardner, R.B. Pearce, R.L. Mitchell, Physiology of crop plants, Terjemahan oleh Susilo and Subiyanto, UI Press, Jakarta, 1991.

[10] E.E. Hansen, J.F. Hubstenberger, G.C. Phillips, Regeneration of shoots from cell suspensionderived protoplasts of Allium cepa, Plant Cell Report 15, 1995, pp. 8-11.

[11] M. Nitis, K. Lana, T.G.O. Susila, S. Uchida, Chemical composition of the grass, shrub, and tree leaves in Bali, Project byproducts (Bali), Centre file: 3-P-77-0087 (IDRC), Suplementary report, Udayana University, Denpasar, 1985.

[12] Suprapto, N.P. Suratmini, Adijaya, Performance of three superior varieties of maize on dry land village of PatasGerokgak, Buleleng, in: Proceeding of 
national seminar on revitalizing creative technology supporting agribusiness and regional autonomy, Denpasar, $7^{\text {th }}$ October200, 2004.

[13] M.C. Zong, Y. Li, Z. Zhang, Plant growth regulators used in propagation, CRC Press, Florida, 2008.

[14] M.S. Haque, T. Wada, K. Hattori, High Frequency Shoot Regeneration and Plantlet Formation from Root Tip Garlic, Plant Cell Tissue and Organ Culture, 50, 1997, pp. 83-89.

[15] M.J. Ludwig, Indole-3-butyric acid in plant growth and development, Journal of Plant Growth Regul, 32, 2000, pp. 219-230.

[16] P. Goyal, K. Sumita, S.L. Kothari, Micropropagation of Pithecellobiumdulce Roxbmultipurpose leguminous tree and assessment of genetic fidelity of micropropagated plants using molecular markers, Physiol Mol Biol Plant, 2, 2012, pp. 18-19.

[17] R. Schubart, Dithiocarbamic acid and derivatives: Ullmann's encyclopedia of industrial chemistry, Wiley-VCH, Weinheim, 2000.

[18] Q. Jian, N. He, Y. Wang, Z. Xian, Ecological issues of mulberry and sustainable development, Journal of Resources and Ecology, 2, 2013, pp. 330-339.

[19] D. Nithya, R.P. Poornima, V. Murugan, M. Gopikrishnan, D.B.R. Radhakrishnan, Balagurunathan, Influence of biofertilizer and irrigation system for the growth and yield of mulberry plants, International Journal of Plant, Animal and Environmental Sciences, 1, 2011, pp. 93-99.

[20] M.S. Rathore, Y.R. Srinivasulu, G.M. Kour, A. Darzi, M.A.K. Dhar, Integrated soil nutrient management in mulberry under temperate conditions, European Journal of Biological Sciences, 3(4), 2011, pp. 105-111.

[21] X.H. Huang, X.H. Yin, Y. Liu, J.X. Li, X.Z. Xiong, Y. Chen, 2012 Effects of drought stress on growth of mulberry (Morus alba) trees in the hydro fluctuation belt of the three gorges reservoir area, Journal of Chongqing University Natural Science 3, 2012, pp. 151-155.

[22] K.R. Stone, Morus alba Fire effects information system, US Department of Agriculture, Forest Service, Rocky Mountain Research Station, Fire Sciences Laboratory, 2009, pp 23-30. 